\title{
Christelike universiteit en politiek in 'n apartheids- en post-apartheidsbedeling'
}

\author{
M. Elaine Botha \\ Departement Filosofie \\ Potchefstroomse Universiteit vir $\mathrm{CHO}$ \\ POTCHEFSTROOM
}

Christian university and politics in an apartheid and post apartheid society

\begin{abstract}
An university is always integrally related to its surrounding culture. The critical question in this regard is the extent to which it takes its cues for the fulfilment of its task from the political establishment within which it is situated and has to function. This issue has historically been of central significance to the Potchefstroom University for Christian Higher Education and still represents a challenge within the new political dispensation. It is argued that the PU for CHE's understanding of the nature of a Christian university and Christian scholarship was influenced, even determined by its uncritical political position within the apartheid society, that this state of affairs was not addressed by the apolitical stance advocated by the university authorities and even less by the Christian philosophy of H.G. Stoker. This stance towards the political dispensation needs radical rethinking in the light of challenges posed by die post-apartheid political dispensation.
\end{abstract}

\section{Christelike Universiteit: op die kruispunt}

Die viering van die 125-jarige bestaan van die PU vir CHO in 1994 as Afrikaanstalige Christelike universiteit noodsaak gelyktydig aanleiding tot bestekopname ten opsigte van die verlede en 'n vooruitskouing op die toekoms. Sentraal staan in albei blikrigtings die vraag na die fundering van die 'Christelike' karakter van die universiteit en die wyse waarop dit in die verlede vorm gegee is en in die toekoms in ' $n$ nuwe politieke bedeling gestalte sal moet aanneem. In die lig van die ingrypende politieke veranderinge wat juis die jaar 1994 kenmerk,

I Hicrdic artikel is oorspronklik voorgelê gedurende Mei $1994 \mathrm{en}$ is in Oktober 1994 gocdgekeur vir publikasic in Koers 
ontstaan die vraag onwillekeurig hoe dit moontlik was dat die PU vir $\mathrm{CHO}$ tydens die afgelope 125 jaar van sy bestaan as Christelike universiteit - qua universiteit - so weinig amptelik standpunt ingeneem het teenoor die diskriminerende politieke sisteem waarin hy vir die grootste deel van sy bestaan ingebed was. Dit bly 'n vraag waarop die jonger generasie ' $n$ antwoord sal eis. Vir diegene wat intiem gemoeid was met die wording en ontwikkelingstryd van die $\mathrm{PU}$ vir $\mathrm{CHO}$ is die antwoord op die vraag bykans voor die hand liggend: die $\mathrm{PU}$ vir $\mathrm{CHO}$ was 'n Afrikaanse universiteit en het sy Christelike karakter duidelik geïnterpreteer teen die agtergrond van sy verbondenheid met die geskiedenis van die Afrikanervolk. Hoe begryplik hierdie antwoord ook al is, eis 'n konsekwent reformatoriese lewensbeskouing nogtans 'n kritiese evaluering van hierdie bykans vanselfsprekende verbintenis.

Net so vanselfsprekend as wat die historiese verbondenheid van die Christelike karakter van die $\mathrm{PU}$ vir $\mathrm{CHO}$ met die kultuur-historiese en politieke aspirasies van die Afrikanervolk vir die meerderheid dosente en studente van die verlede was, net so onbegryplik is dieselfde stand van sake vir 'n jonger generasie akademici en studente wat óf die slagoffers was van die diskriminasie so eie aan die apartheidsisteem of die innerlike disintegrasie van die 'apartheidsisteem' van naderby meegemaak het of konstruktief help bevorder het. Problematies is veral dan ook die kritieklose wyse waarop die filosofiese en teologiese regverdiging van 'n dergelike verbondenheid deur figure soos Stoker en ander deur talle akademici en studente van die verlede aanvaar is. Wat des te meer vrae oproep, is hoe dit moontlik was dat ' $n$ figuur soos Stoker wat bereid was om so radikaal posisie in te neem ten opsigte van die religieuse bepaaldheid van wetenskaplike kennis, tog nie die konsekwensies van hierdie radikale geloofstellingname ook konsistent deurgetrek het na die verstrengeling van die universiteit met die nasionale en politieke lewe nie. Die bydrae van H.G. Stoker, die Calvinistiese filosoof van Potchefstroom, wat as akademikus sowel nasionaal as internasionaal bekendheid verwerf het, het met sy besinning oor die wetenskap, Christelike wetenskap en die verhouding tussen wetenskap, universiteit en kultuur dan ook 'n belangrike bousteen gelewer vir die besinning oor die plek en taak van die Christelike universiteit te midde van ' $n$ bepaalde politieke bedeling. Te midde van hierdie vrae met betrekking tot die politieke stellingname van die PU vir $\mathrm{CHO}$ in die verlede, bly die vraag na en die verantwoording van die "Christelike" karakter van die $\mathrm{PU}$ vir $\mathrm{CHO}$ in die brandpunt - des te meer in die lig van gewysigde politieke omstandighede.

Dit is die opset van die eerste deel van hierdie artikel om an te toon dat die 'Christelike' karakter van die PU vir $\mathrm{CHO}$ in die gang van die geskiedenis baie sterk die cachet van die dominante politiek-ideologiese denkbeelde van 'n spesifieke era gereflekteer het en dat H.G. Stoker se besinning oor die wetenskap, universiteit en akademiese vryheid hierdie politieke dienstigheid versterk het 
eerder as om profeties-krities daarteenoor stelling in te neem. Die besinning sal geanker word in enkele belangrike gebeure en ontwikkelingsfases in die geskiedenis van die PU vir $\mathrm{CHO}$ waaruit duidelik historiese brandpunte rondom die idee van 'n Christelike universiteit na vore getree het. Uit die posisionering van die PU teenoor historiese gebeure en situasies sal dit blyk dat die profiel van wat onder 'Christelik' verstaan word, telkens 'n nuansering ondergaan het wat gekorreleer het met die kulturele en politieke situasie van 'n bepaalde tydstip. ${ }^{2}$ So byvoorbeeld was die Britse imperialisme vir 'n geruime tyd die duidelike vyand waarteenoor die Afrikaanse universiteite en by name die $\mathrm{PU}$ vir $\mathrm{CHO}$ stelling ingeneem het - vandaar die sterk assosiasie tussen die Christelike identiteit van die PU en die Christelik-nasionale ideale van die Afrikanervolk. Die stryd teen die gewetensklousule en die erkenning as selfstandige instelling vir Christelike hoër onderwys verteenwoordig ' $n$ verdere belangrike brandpunt, wat duidelik daartoe bygedra het dat die Christelike identiteit van die PU duideliker vorm aangeneem het. Die sewentigerjare van hierdie eeu konfronteer die universiteit met ' $n$ ander uitdaging: die verhouding met die Vrije Universiteit van Amsterdam en ander geesgenootlike Christelike inrigtings wêreldwyd, stel die universiteit voor die vraag na die verantwoording ten opsigte van sy maatskappykritiese funksie in 'n diskriminerende apartheidsamelewing. Tans kom die bedreiging vir die karakter van die Christelike universiteit waarskynlik eerder van die relatiwisme so kenmerkend van die post-modernistiese kultuur waarbinne die universiteit moet funksioneer. Die post-apartheidsamelewing wat ook tot 'n hoë mate deur die post-modernisme gekenmerk sal word, eis van die Christelike universiteit om van binne uit reformatories te besin oor sy unieke bydrae tot die sogenaamde transformasieproses van die samelewing en die voorgestelde proses van rekonstruksie en ontwikkeling en die akkommodasie van multikulturalisme Elkeen van hierdie brandpunte en historiese gebeurtenisse dra daartoe by dat die identiteit van die PU as Christelike universiteit op 'n nuwe wyse verantwoord word. Dat daar aan die bestaan van die Christelike universiteit veel meer kante onderskeibaar is as wat hier aan die orde gestel kan word, spreek vanself. In die tweede deel van hierdie artikel sal op ' $n$ meer sistematies-normatiewe wyse gekyk word na die idee van 'n Christelike universiteit in die lig van die gewysigde politieke situasie en die eise van ' $n$ nuwe bedeling.

\section{Geen polities of religieus neutrale universiteit nie}

Dat die universiteit ten nouste verstrengel is met die samelewing en daarby ingesluit ook die politiek van 'n bepaalde era, verg weinig betoog. Die kritiese

\footnotetext{
2 Hierdic toedrag van sake geld nie net vir die PU vir CHO nie, maar is ook kenmerkend van dic korrclasic tussen die ontwikkelinge van die Suid-Afrikaanse universiteitswese en die wisselende politicke bedelinge in die algemeen
} 
vraag wat ten opsigte van hierdie verstrengeling ten opsigte van sowel die verlede as die toekoms gevra moet word, is watter implisiete of eksplisiete standpunt die universiteit ten opsigte van die politiek en die aktuele samelewingsvraagstukke van 'n bepaalde era ingeneem het of in die toekoms sal inneem. Watter riglyne sal ten opsigte van hierdie betrokkenheid as maatstawwe diens doen? In die literatuur oor die verstrengeling van universiteit en politieke samelewing word twee teenoormekaarstaande standpunte aangetref: Enersyds die onvermydelike politiese betrokkenheid van die universiteit, en andersyds die idee van die sogenaamde 'neutrale' of a-politiese universiteit. Die sitaat van Wallerstein (1969:11) dui op die eersgenoemde standpunt, naamlik die onvermydelike politiese betrokkenheid van die universiteit:

It is a political act for the university to support the government in its normal functions. It is a political act for the university to be indifferent to the government. It is a political act for the university to oppose the government. However it acts in its relation to the govemment, the university is engaged in politics.

Lynreg hierteenoor staan die standpunt van iemand soos Philip M. Hauser (1975: 270) wat redeneer dat die universiteit essensieel a-polities is en geroepe is om 'n unieke nie-politiese missie te vervul. Sy standpunt word ontwikkel in samehang met die Weber-tese oor die waardevryheid van die wetenskap. Hoewel albei standpunte eensydig is, omlyn hulle tog tot 'n hoë mate die problematiek waarvoor die Christelike universiteit in die verlede met betrekking tot die verhouding tot die politieke bestel gestel was en beslis weer eens in die toekoms te staan sal kom.

Die vraag ontstaan waarom die PU vir $\mathrm{CHO}$, wat so onverskrokke bereid was om standpunt in te neem met betrekking tot die religieuse en lewensbeskoulike bepaaldheid van onderwys, opvoeding en wetenskap nie vanuit daardie selfde fundamentele religieuse stellingname profeties-krities ingestel was teenoor die verontregting en diskriminasie wat integraal deel was van die politieke bestel waarbinne die universiteit ingebed was nie. ${ }^{3}$ Die kompleksiteit van die problematiek oor die verhouding van universiteit en samelewing kom na vore in Stoker se poging om vanuit sy reformatoriese visie die verhouding tussen apartheid en akademiese en universitêre vryheid te omlyn. Hoewel Stoker veel geskryf het oor die beginselstryd van die PU om erkenning as Christelike universiteit, is daar nie

3 Dat daar op Potchefstroom oor die jare heen altyd sogenaamde 'dissenting voices' was, staan vas. Vandaar dan ook die benaming van die 'stem van Potchefstroom' wat in die pers en politiek bekendheid verwerf het. Die punt is egter dat hierdic verset nooit formele en amptelike verset van die universiteitsowerheid teen die heersende onregverdige en diskriminatoriese politieke praktyke en beleid was nie 
M. Elaine Botha

te veel van sy publikasies waarin eksplisiet aandag geskenk word aan die verhouding tussen universiteit en samelewing nie. Net soos vele van sy tydgenote was Stoker gewortel in die bestaanstryd van die Afrikaner en sy kultuur; ' $n$ verworteling wat hom waarskynlik minder krities teenoor die inherent onregverdige apartheidsisteem laat staan het. Vervolgens word kortliks stilgestaan by sy verantwoording oor die verhouding van die Christelike universiteit en die beleid van apartheid.

\section{H.G. Stoker: akademiese vryheid, universitêre vryheid en apartheid}

Stoker se visie op die verhouding tussen apartheid en akademiese vryheid moet teen die agtergrond van sy visie op rasse en die volk as primêre samelewingsverband gesien word.

Stoker $(1967: 210,211)$ stel onomwonde in sy artikel "At the crossroads: Apartheid and University Freedom in South Africa" (aanvanklik gepubliseer in 1957) op die vraag of rasseskeiding van studente op enige wyse universitêre vryheid verkrag : “... I give my personal view, which is, as far as I can see, fundamentally in agreement with the South African Government's policy of apartheid".

Die kern van die artikel is gewy aan die vraag of die verbod dat "Bantu students" aan (blanke) "Europese" universiteite mag inskryf of dit bywoon, in stryd is met universitêre vryheid al dan nie. Hy werk in hierdie artikel oorwegend met die teenstelling tussen Europeans en Bantu as rassegroepe. "Racial" word egter telkens gevolg deur "(resp. national)".

Stoker (1967:213) stel dat apartheid primêr die verhouding tussen menslike groepe beklemtoon, dat dit die beginsel van die universele gelykheid van alle mense en van menslike vryheid aanvaar - 'n aanvaarding "... primarily in respect of racial groups". Apartheid erken ook, volgens Stoker (1967:213) die beginsel van ekwivalente differensiasie van mense (weer eens, "..primarily with respect to racial groups") en van hulle vryhede. Rassegroepe besit 'n eie individualiteit en lewenswyse en apartheid wil juis elk van die rasse beskerm ten einde dit tot sy hoogs moontlike ontwikkeling ooreenkomstig sy aard ("nature") en vermoëns te voer. Bestaande diskriminasie teen die Bantoegroep moet, namate die Bantoegroep ontwikkel, opgehef word (Stoker, 1967:214). Diegene onder die Bantoeras wat reeds 'n ontwikkelingspeil bereik het wat dié van hulle eie groep te bowe gaan, sê Stoker (1967:214) is die " ... unhappy victims of a transitional phase of bantu development". Hierdie ontwikkelingsfase tipeer Stoker as 'n "puberteitsfase" wat van sowel die "kind" as die "ouer" aanpassing verg. Juis die uitgebreide en toenemend snelle ekonomiese integrasie van die verstedelikte Bantoe en 
Europeërs het juis die kritieke ontwikkelingsfase in 'n rassekrisis laat verander. Hierdie krisis dwing Suid-Afrika, sê Stoker (1967:215) om 'n finale keuse te maak tussen integrasie en differensiasie. Duidelik stel hy (1967:216) dat daar geen middeweg tussen apartheid en integrasie is nie aangesien integrasie tot assimilasie sou lei.

Ten opsigte van die vraag na akademiese vryheid voer Stoker (1967:217) die onderskeiding tussen 'akademiese' en 'universitêre' vryheid in ten einde te differensieer tussen die vryhede wat 'des universiteits' is en daardie vryhede wat gebonde is aan die vryheid van die universiteit om die eie rassegroep te dien. In die lig hiervan stel hy (Stoker 1967:218):

... the ideal of a policy of integration, namely that a university should not serve only a section of the country, but that it should have a multiracial character, and be a cross-section of the racial composition of South Africa, appears to be unacceptable.

Hy som sy eie argumentasie op deur te konkludeer dat die regering van SuidAfrika 'n goeie saak het vir die vestiging van aparte "Non-European" universiteite.

Wanneer hy die belangrike vraag bespreek of die verbod op die toelating van Bantoe-studente aan Europese (blanke) universiteite nie dalk in stryd is met universiteitsvryheid nie, redeneer hy dat die maatstaf vir sodanige toelating die vraag is of ' $n$ aantal voorwaardes nagekom is, te wete: of die patroon van apartheid gerealiseer is, die gevaar van assimilasie en integrasie afgeweer is en rekening gehou is met die feit dat die toelating van sulke studente nie die nasionale (of rasse-) belange van ' $n$ betrokke land bedreig of die nasionale en rassekarakter van die universiteit in gevaar stel nie. Hy neem dan ook veral die sogenaamde 'oop' universiteite kwalik dat hulle toelatingsvereistes nie op "akademiese gronde" bepaal word nie maar op grond van die voorwetenskaplike beginsels van die "liberalisme" (Stoker, 1967:221). Daarteenoor argumenteer hy dat universitêre differensiasie streng toegepas behoort te word ten einde die patroon van 'gedifferensieerde ontwikkeling' te vestig en te bevestig. Wanneer dit bereik is en die Bantoevolke ' $n$ beskawingspeil bereik het wat in ooreenstemming is met dié van die blankes, dan kan daar geen beswaar bestaan nie dat per uitsondering (Stoker kursiveer, 1967:221, nota 48), byvoorbeeld 'n nagraadse student van een ras onder ' $n$ deskundige aan ' $n$ universiteit van ' $n$ ander ras sal studeer, soos dit ook aan buitelandse universiteite per uitsondering (Stoker se kursivering) geskied. Sodanige verbod op die toelating van studente van ander rassegroepe tot universiteite beskou Stoker nie as 'n skending van akademiese vryheid nie, omdat hy die vryheid skerp onderskei het van universitêre vryheid. Dit is duidelik dat een van die kardinale aspekte van Stoker se visie op die verhouding van universiteit en apartheidsbeleid te make het met die goedkeuring en regverdiging van 
die toelatingsverbod van rassegroepe wat vir ' $n$ lang tyd so kenmerkend was van die politieke beleid van apartheid.

Veel sou waarskynlik oor die visie van Stoker gesê moet word: hier word voorlopig met enkele opmerkings volstaan:

* Eerstens was sy uitsprake tydgebonde soos alle ander wetenskaplike werk en moet dit dus binne die konteks van die tyd gesien en beoordeel word. Sodanige erkenning het altyd twee kante: enersyds wek dit deernis en begrip en gee dit aanleiding tot ' $n$ relativering van die kritiese oordeel. Andersyds kan dit op geen enkele wyse as verskoning dien vir 'n onkritiese akkommodasie van filosofiese en ideologiese denkbeelde van 'n spesifieke era nie.

* Tweedens werk hy gemaklik met die teenstelling tussen "Europeans" en "Bantu" as rassegroepe en die rassegroepe vervloei dan gemaklik in "nasionale" groepe. Hier skyn dus weinig blyke te wees van die skerp onderskeidinge wat hy elders (Stoker, 1961:172) maak tussen staat, volk en nasie. Meer nog, sy denke toon duidelik 'n voorkeur vir 'n Eurosentriese elitistiese beskawingsfilosofie. Hier werk dus 'n bedenklike beskawingsfilosofie deur wat die ontwikkelingspeil van die "European" as uitgangspunt neem en die Bantu gelyke regte en geleenthede gun, wanneer hulle eers die beskawingspeil van eersgenoemde groep bereik het.

* Derdens verwyt hy die 'Liberalisme' hulle voorwetenskaplike vertrekpunte, terwyl hy self nie erken dat sy eie (onkritiese) sanksionering van die SuidAfrikaanse regering se apartheidsbeleid op net sulke sterk 'voorwetenskaplike' uitgangspunte berus nie. Hy het by voorbaat gekies vir die primaat van die groeps-, respektiewelik rasse- (respektiewelik nasionale) verbondenheid van die universiteit en daardie verbondenheid sterk rassisties ingekleur. Die beginsels van gelykheid en vryheid is sterk gekoppel aan die mate van ontwikkelingsdifferensiasie van (rasse-)groepe en daar word ' $n$ sterk teenstelling tussen "Europeanisation"/"Westernisation" en "Bantu-fication" geponeer (Stoker, 1967:213).

* Vierdens word hier 'n hoogs geforseerde en kunsmatige onderskeiding tussen 'akademiese' en 'universitêre' vryheid ingevoer, wat dit moontlik maak om die bestaan van aparte universiteite vir verskillende rassegroepe te regverdig.

" Samevattend is dit duidelik dat die verbod op die toelating van "Bantoe"studente tot die 'Europese Westerse' universiteit die aanvaarbare riglyn was vir die beskerming van die laasgenoemde rassegroep teen assimilasie en integrasie. Tot op sekere hoogte het Stoker slegs op meer filosofies-gesofistikeerde wyse verwoord wat in elk geval oor jare heen die amptelike beleid 
Christelike universiteit en politiek in 'n apartheids-en post-apartheidsbedeling

en praktyk van die PU vir CHO was. Die denkspoor word ook in die ontwikkelingsgang van die $\mathrm{PU}$ vir $\mathrm{CHO}$ gesien.

\section{Geen a-religieuse wetenskap}

In Stoker se onvermoeide ywer vir die saak van Christelike wetenskap het daar egter' $n$ sterk profeties-kritiese dimensie deurgewerk ${ }^{4}$. Die groot kontoere van sy wetenskaplike arbeid het ook oorwegend in die teken gestaan van die proklamering van die radikaliteit van die religieuse bepaaldheid van die kenne, die denke en die wete en vandaar dan ook dat hy in die vyftigerjare een van die sterkste kampvegters vir die erkenning van die $\mathrm{PU}$ vir $\mathrm{CHO}$ as selfstandige Christelike universiteit was. Die PU vir $\mathrm{CHO}$ het in die loop van sy ontwikkeling en geskiedenis op ' $n$ wye front probeer gestalte gee aan sy roeping as Christelike universiteit. Die toepassing van die keuringsbeginsel vir die benoeming van dosente was moontlik een van die sterkste voorwaardes vir die verwesenliking van hierdie ideaal. In onderrig, navorsing en gemeenskapsdiens het PU-dosente en studente 'n dikwels moeisame weg gesoek en gevolg om die diepste oortuigings van die Christelike lewens- en wêreldbeskouing in die universiteit en die wetenskap gestalte te gee. In hierdie werk het professor H.G. Stoker ook 'n onmiskenbare bydrae gelewer met sy besinning oor die aard van Christelike wetenskapsbeoefening en die plek van die wetenskap en wetenskaplike metodes. Vanaf die vroegste jare is spesiale kursusse aangebied waarin juis hierdie unieke Christelike karakter van die universiteit tot uitdrukking gebring kon word. Hierdie kursusse het onder meer Geloofsleer, Beginsel- en Metodeleer, Studium Universale, Studium Generale, Etiek en Logika, Interfakultêre Wysbegeerte, ensovoorts ingesluit.

Tans word daar aan die PU vir CHO in alle fakulteite gespesialiseerde kursusse aangebied waarin juis die algemeen wysgerige vorming en vakfilosofiese vorming vanuit 'n Christelike lewens-en wêreldbeskouing en vanuit 'n Christelik-filosofiese raamwerk aan die orde gestel word. In hierdie verband moet die bydrae van die Departement Filosofie nie onderskat word nie. Vanaf die vroegste jare het hierdie departement met figure soos proff. H.G. Stoker, J.A.L. Taljaard, B. Duvenage, N.T. van der Merwe en andere 'n daadwerklike bydrae gelewer tot die besinning oor die aard van Christelike wetenskapsbeoefening en die karakter van 'n Christelike universiteit. En tog bly die vraag of die PU vir CHO nie mede deur sy gebondenheid aan en betrokkenheid by die kultuur en politiek van die

4 Vir die doeleindes van hierdie artikel word die diskussie van die moontlike en/of werklike deurwerking van Skolastiese elemente in die filosofie en wetenskapsfilosofie van Stoker buite rekening gelaat, hoewel dit in 'n diskussie van sy visie op Christelike wetenskap wel deeglik ter sake is. 
Afrikaner, dalk onvoldoende afstand geneem het van die politieke beleid van die spesifieke era nie.

\section{Die PU vir CHO: polities-neutraal?}

\subsection{Ontwikkelingsfases}

In die geskiedenis van die Suid-Afrikaanse universiteitswese is die PU vir CHO nie die enigste instelling wat vanaf sy ontstaan bewustelik op Christelike grondslag wou staan nie. Verskeie ander instellinge in die land, waar onder Victoria College, Lovedale College (Fort Hare Universiteit) ensovoorts, het ook aanvanklik as Christelike onderwysinstellinge die lig gesien, maar het met verloop van tyd 'n duidelike karakterverandering ondergaan. Die idee van 'n vrye, selfstandige Christelike universiteit het sy wortels sowel in die Europese kultuur as in die Afrikaanse kultuurbodem. Die ontwikkelde vrug van Christelike hoër onderwys in die RSA toon in die historiese ontwikkelingsgang daarvan baie duidelik die inslag en invloed van die onderskeie groeibodems. Tog het die plant van die PU vir $\mathrm{CHO}$ as Christelike universiteit in die historiese ontwikkelingsgang in die RSA onmiskenbare ontwikkelingsfases meegemaak waarin die deurslaggewende invloed van tipies Afrikaanse groeifaktore duidelik merkbaar is. Die volgende ontwikkelingsfases sou onderskei kon word:

1. Die ontstaan en ontwikkeling van die Teologiese Skool van die Gereformeerde Kerk te Burgersdorp in 1869 en die ontwikkeling van onderwysersopleiding en 'n literariese fakulteit uit hierdie opleiding.

2. Die stryd om die vrystelling van die bepalings van die gewetensklousule en die bestaansreg as selfstandige Christelike universiteit.

3. Die vestiging van die Christelik-nasionale en/of 'Christelik-historiese' karakter van die PU as Christelike universiteit in die veertigerjare

4. Internasionale vervreemding in die sewentigerjare as gevolg van meningsverskille oor die implikasies van die Christelike geloof vir die kritiese beoordeling van kwessies oor rassegeregtigheid en die betrokkenheid van die universiteit by die beleid van afsonderlike ontwikkeling ('apartheid').

5. Die Christelike universiteit te midde van 'n oorgang na 'n post-apartheidssamelewing en die Christelike universiteit in die gesekulariseerde post-moderne kultuur.

Die indeling in verskillende fases is gebonde aan bepaalde historiese ontwikkelinge en is ook onlosmaaklik verbonde aan die deurwerking van verskillende politieke denkbeelde en die kenmerkende histories-gesitueerde reaksie en inspeling op hierdie omstandighede en denkbeelde deur die PU vir CHO. Hiervan is die keuringsbeginsel vir dosente en die toelating van studente 'n belangrike baken. 


\subsection{Die keuringsbeginsel as waarborg vir die Christelike karakter van die PU vir CHO}

Een van die belangrike maatstawwe met betrekking tot die implementering van die Christelike karakter van die $\mathrm{PU}$ vir $\mathrm{CHO}$ was die keuringsmodel vir studente en dosente wat in die onderskeie fases van die geskiedenis van die PU gehandhaaf was. By die totstandkoming van die Teologiese Skool van die Gereformeerde Kerk in Suid-Afrika te Burgersdorp en die oorplasing daarvan na Potchefstroom is daar duidelike kriteria geformuleer vir die keuring van die studente wat tot die inrigting toegelaat sou word: lidmaatskap van die Gereformeerde Kerk. Die keuringsmodel wat die stigters van die inrigting gebruik het om hulle partikulariteit te beskerm, het met verloop van tyd egter verander. Toe die Potchefstroomse Universiteitskollege in 1921 een van die konstituerende kolleges van die Universiteit van Suid-Afrika geword het, moes die keuringsbeginsel vir toelating van sowel die studente as dosente verval. Die inrigting het egter die reg behou om die keuringsbeginsel steeds toe te pas met betrekking tot die benoeming van personeel deur vrystelling te verkry van klousule 25 van Wet no. 12 van $1916-$ die sogenaamde gewetensklousule (Reinecke, 1989:415 - 431).

'n Ander keuringsbeginsel wat deur die universiteit vir 'n groot deel van sy bestaan gehandhaaf is, was die nie-toelating van gekleurde en swart studente tot die universiteit - 'n saak wat later 'n steen des aanstoots in die verhouding van die PU tot ander Christelike instellings vir hoër onderwys elders ter wêreld geword het. Hoewel die nie-toelating van anderskleurige studente tot blanke universiteite sedert ongeveer 1948 die algemene owerheidsbeleid in die RSA was, was daar verskeie Suid-Afrikaanse Engelstalige universiteite wat hulle weg mettertyd wel daartoe oopgesien het om juis hierdie owerheidseis te omseil. Die PU het egter tot in 1972 geen anderskleurige studente op voor- en nagraadse vlak toegelaat nie; vanaf 1973 slegs studente op nagraadse vlak. Vanaf 1984 is anderskleurige studente "... op nagraadse vlak en selektief op voorgraadse na-uurse vlak" tot voltydse studie toegelaat, maar nog steeds onder die voorbehoud dat hulle slegs klasse mag bywoon en nie volledig in die koshuise gehuisves kon word of in die studentesamelewing mag deelneem nie ${ }^{5}$. Eers vanaf 1990 is anderskleurige studente sowel op voor- as nagraadse vlak as volwaardige studente tot die universiteit toegelaat en in die universiteitskoshuise gehuisves. Moontlik sou juis hierdie twee historiese keuringskriteria gesien kon word as belangrike spitse met betrekking tot die wyse waarop die Christelike karakter van die universiteit as

5 $\mathrm{Vgl}$. "Ook word hulle deelname aan die PU vir $\mathrm{CHO}$ tans toegespits op akademiese werk, en moet elke sweem van integrasie (anders as dialoog en kontak) vermy word. Die PU vir CHO bied ook nie huisvesting aan hierdie studente nie". (Nuusbrief na die Raadsvergadering, 22 Junie 1984.) 
M. Elaine Botha

'Christelik-histories' of 'Christelik-nasionaal' geïnterpreteer was. Aan die een kant was daar die onkritiese verbondenheid met die heersende owerheidsbeleid; aan die ander kant 'n opregte oortuiging by besluitnemers dat 'Christelik' per definisie die nasionale en historiese kultuurverbintenis impliseer en dat assimilasie en integrasie (selfs van anderskleurige geloofsgenote) ongewensd was. In hierdie opsig was Stoker se standpunt geen uitsondering nie.

Hoewel die PU in sy diskussies met die Vrije Universiteit van Amsterdam, Nederland in 1975/76 duidelik laat blyk het dat die universiteit geen eksplisiete standpunt met betrekking tot die politiek voorstaan nie, het die besluite rondom die aanvanklike uitsluiting en later stapsgewyse toelating van anderskleurige studente duidelik laat blyk dat die PU allermins a-kultureel of a-polities was. Sy stilswygende aanvaarding van die owerheidsvoorskrifte van die heersende politieke bestel was eintlik 'n implisiete sanksionering van die bestaande orde (Botha, 1985:20). Positief was dit gemotiveer en gedra deur die wyse waarop die 'Christelik-historiese' karakter geïnterpreteer was. Negatief was dit 'n verskansing van die blanke karakter van die destydse universiteitsgemeenskap. In die Raadsbesluit van die PU geneem op 22 Junie 1984 met betrekking tot die toelating van anderskleurige studente word onder andere in die "Beleid en prinsipiële motivering" die volgende gestel insake die "Christelik-historiese" karakter van die $\mathrm{PU}$ vir $\mathrm{CHO}$ :

1.1 Die Christelike historiese karakter van die PU vir CHO is wetlik en tradisioneel begrond en word gehandhaaf in die strewe tot die beoefening van die Christelike wetenskap, opvoeding in 'n Christelike lewensbeskouing, sowel as in die benoeming van sy akademiese en administratiewe personeel. Daarom is die Universiteit onvoorwaardelik Christelik en onbeskaamd Afrikaans.

1.2 Die Raad is kragtens wet verantwoordelik vir die handhawing van hierdie Christelike historiese karakter en is vasberade om dit onverswak vir die toekoms te handhaaf.

1.3 Alle studente moet hierdie karakter respekteer, ook waar hulle nieChristene (bv. Jode) of nie Afrikaner is nie (bv. Engelse, Amerikaners, Koreane, Tswanas, ensovoorts). Dit is uitdruklik nie die bedoeling van die PU vir CHO om deur die opname van hierdie studente veelgelowig of veelvolkig te word of neutraal ten opsigte van ons godsdiens of ons volk te staan nie. (PU vir CHO 1984 - Raadsbesluit 22 Junie 1984.)

Die Raad het hom met hierdie besluit egter nog streng gehou binne die kader van die landswette wat geïmpliseer het dat daar geen huisvesting vir anderskleurige studente op die kampus voorsien kon word nie en dat "... elke sweem van integrasie (anders as dialoog en kontak) vermy word" (PU vir CHO 1984: 13). In 
Christelike universiteit en politiek in 'n apartheids- en post-apartheidsbedeling

hierdie Raadsbesluit word eksplisiet gestel dat die PU vir CHO hom sal beywer vir die daarstelling van Christelike universiteite vir ander taal- en volksgroeperinge:

Ons sien ondertussen ons bydrae tot die akkommodasie van hierdie ander studente veral daarin dat ons 'n leierskorps help voorberei wat eendag die fondamente kan lê vir hulle eie Christelike universiteit(e) (PU vir CHO 1984 - Raadsbesluit 22 Junie 1984.)

Dit is opmerklik dat hierdie besluit bykans woordeliks die standpunt vertolk wat deur H.G. Stoker reeds in 1957 ten opsigte van die akkommodasie van studente uit ander taal- en volksgroeperinge geformuleer is. Die inkleding van die aard van die Christelik-historiese karakter van die universiteit word ook duidelik gesien in die rektorale intreeredes van rektore van die PU vir CHO deur die loop van die jare.

\subsection{Vormingsjare: Die Christelike-historiese (Christelik-nasionale) karakter van die $\mathrm{PU}$ as Christelike universiteit}

In die rektorale intreeredes van die onderskeie rektore van die $\mathrm{PU}$ vir $\mathrm{CHO}$ word telkens ' $n$ beroep gedoen op die Christelike karakter, roeping en taak van die universiteit. In sodanige beroep word dan verwys na die 'Christelike beginsels', die transendente waardes of die Christelik-historiese karakter van die inrigting. As die intreeredes van die onderskeie rektore as basis gebruik word vir die beoordeling van die betekenisspektrum wat aan die 'Christelike universiteit' geheg word, dan blyk dit dat ${ }^{6}$ in die fase vanaf die vyftiger- tot sewentiger- (tagtiger-?) jare die 'Christelike' karakter van die universiteit onlosmaaklik verstrengel was met die sogenaamde Christelik-historiese of Christelik-nasionale karakter daarvan. In feitlik elkeen van die rektorale intreeredes wat in hierdie fase gelewer word, is daar ' $n$ verwysing na hierdie besondere interpretasie van die Christelike karakter. Dit sou onbillik wees om die 'Christelik-historiese' karakter eenvoudig te identifiseer met die dualistiese en nasionalistiese 'Christelik-nasionale' lading wat dit dikwels later in die geskiedenis van die PU vir $\mathrm{CHO}$ verwerf het. Daar is in die begrip Christelik-histories dan ook sedert die gebruik daarvan deur G. Groen van Prinsterer in Nederland, 'n soort ambivalensie ingebou: enersyds 'n beroep op die reformatoriese erfgoed van die Christendom, andersyds 'n appèl op die waardes en tradisies van die nasionalisme. Hierdie dubbelslagtigheid doen hom ook voor in die verskillende nuanses wat hierdie begrip in die gang van die

$6 \quad$ Metodologies sou hierdie aanpak moontlik aanvegbaar wees. Waarskynlik sou 'n analise van uitsprake van die Raad van die Universiteit oor hierdie kwessie wetenskaplik 'n meer verantwoorde benadering wees. 
geskiedenis van die PU vir CHO kry. H.G. Stoker het in sy verskeie geskrifte hierdie beginsel dan ook helder verwoord:

Die P.U.K. vir C.H.O. - tot dusver die enigste Christelike universiteit in ons land, waar die Christelike wetenskap beoefen word en die studente in $U$ lig gevorm word tot volksleiers (en daarby die enigste $100 \%$ Afr. univ. van ons land) - staan vir dieselfde beginsels waarvoor ons Calvinisties-Afrikaanse volk staan, waarvoor die Voortrekker gestaan het, en daarom is dit seker nie aanmatigend om te sê dat die P.U.K. vir C.H.O. sig prinsipieel in die diepste sin van die woord mag noem:

Ons Afrikaanse Volksuniversiteit

Mag die Afrikaanse volk dit leer besef?

(Stoker-argief, ongedateerde stuk: "Waarom 'n Christelike universiteit?"; vgl. ook Stoker, 1952:13-18).

Hierdie tema van die innige verbondenheid van die Christelike universiteit met die Christelike Afrikaanse volk kom soos ' $n$ refrein in die geskrifte van onder andere die rektore in dié tyd voor. Die eerste rektor van die PU, prof. Ferdinand Postma het onomwonde gestel:

Die onderwys moet nasionaal wees. Die beginsel waanit die PUK geleef het, is die van nasiebewustheid, nasiegetrouheid en nasieliefde. Die jeug moet opgevoed word in die onwrikbare geloof in die Godgegewe taak en roeping van die Afrikaanse volk. Dis die nasionale beginsel van die P.U.K.

(Puk aksiekomitee-pamflet, 21 Mei 1984).

Rektor J. Chris Coetzee (1954:31) sê byvoorbeeld:

Maar die universiteit het teenoor die volk en die land as ' $n$ geheel ook nog 'n ander belangrike roeping. Dit moet ook sorg dra vir die behoud en oordrag van die nasionale kultuur; dit moet dus voorsiening maak vir die onderrig en leiding ten opsigte van die belangrikste aspekte van die nasionale kultuur. Elke universiteit moet ' $n$ nasionale karakter dra en elke Christelike universiteit ' $n$ Christelik-nasionale karakter.

Vergelyk ook die standpunt van H.J.J. Bingle (1964:481, 9):

Hy (die universiteit - red.) lewer mense aan volk en kerk; hy bou dus aan die nasionale kultuur skeppend en aan die Gereformeerde leer en lewe. En hierdie sake kan alleen gedien word as die geestelike leiers die volk reg voorgaan in beskouing oor wêreld en lewe. Groot is die verantwoordelikheid van die P.U. vir C.H.O. in hierdie verband sodat die bakens van die volk nie versit sal word nie en dat hy inderdaad Christelik-Nasionaal sal bly. 
Christelike universiteit en politiek in 'n apartheids-en post-apartheidsbedeling

Moontlik is die mees kernagtige uitdrukking van hierdie gedagte die bekende uitspraak van rektor Tjaart van der Walt, $(1978: 10,11)$ ten opsigte van die karakter van die $\mathrm{PU}$ vir $\mathrm{CHO}$ as Christelike universiteit: “... onvoorwaardelik Christelik ... onbeskaamd Afrikaans ...".

In die wysiging van die Privaatwet van die $\mathrm{PU}$ vir $\mathrm{CHO}$ in 1992 vind egter 'n geringe klemverskuiwing plaas

Die nuwe taalklousule bevestig daarenteen egter sowel die kulturele karakter van die universiteit as sy ingesteldheid tot diens-lewering ongeag taal ... Die tyd vir kulturele eksklusiwiteit is finaal verby. (Reinecke, 1992a:18, 19.)

Hierdie Christelik-historiese karakter is egter nêrens skerp omlyn nie. Tot op sekere hoogte het dit in die toelatingsbeleid en die (rasse-)keuringsbeginsel geblyk en verder het dit in die verstrengeling van die universiteit met Afrikaanse kerke, kultuur en politiek tot vergestalting gekom.

In die "Beginselgrondslag van diensverhouding en reglement betreffende benoeming en diensvoorwaardes" (1981) van die personeel van die PU vir CHO, word in afdeling A telkens verwys na die Christelik-historiese karakter van die universiteit en die Christelike historiese beginsels van die Universiteit. Maar die presiese inhoud en reikwydte hiervan word nie verder in die dokument uitgewerk nie. Waarskynlik is hierdie bepalings geinterpreteer in die breë sin van die sogenaamde 'Christelik-nasionale' beginsel, waarop daar in ander universiteitsgeskrifte so sterk ' $n$ beroep gedoen was. In die praktyk het dit 'n bepaalde integraalCalvinistiese lewens- en wêreldbeskouing gëmpliseer waarin die soewereiniteit van God en sy wet en die koningskap van Christus oor alle lewensterreine sentraal gestaan het. Die koningskap van Christus het die terrein van die wetenskap ook ingesluit. Wetenskaplike onderrig en navorsing moes dan vanuit hierdie grondgedagte ontwikkel word. Net so sterk was die Christelik-historiese karakter egter geïnterpreteer as die verbondenheid aan die Afrikanervolk en -taal en die historiese kultuureie van die Afrikanervolk - so sterk selfs dat dit vir die universiteit bykans onmoontlik was om teenoor die onregverdige politieke beleid en praktyke van die Nasionale Party krities standpunt in te neem. Ter regverdiging hiervan het die Rektor van die PU, prof. Bingle, in die diskussie met verteenwoordigers van die Vrije Universiteit van Amsterdam, betoog dat die wyse waarop die PU sy taak verstaan het, kritiek op politieke praktyk en beleid van die owerheid uitsluit, behalwe in soverre dit begrensde universitêre aangeleenthede raak (V.U., 1976).

Uit die voorafgaande gegewens sou twee argumentasielyne kon ontwikkel: Enersyds kan geargumenteer word dat die interpretasie van 'Christelik-nasionaal' en 'Christelik-histories' niks meer as 'n kulturele verbondenheid tussen die taak van 
die PU en die Afrikanervolkskultuur voorstel nie. Andersyds is dit egter moeilik om juis hierdie ideaal los te maak van die politieke aspirasies en uiteindelike politieke magsposisie van die Afrikaner. Die oorwegende konklusie is myns insiens dat die PU vir die grootste deel van sy bestaan beslis nie a-polities was nie; inteendeel - die PU was dikwels juis sterk polities betrokke of implisiet gekompromitteer aan die heersende politieke beleid. Op hierdie punt was die duidelike ondersteuning van die Ossewa Brandwag en standpuntinname van Stoker en talle ander PU-akademici teenoor die deelname aan die Tweede Wêreldoorlog ' $n$ uitsondering. Aan die Universiteit was daar in dié tyd uiteraard ondersteuners van die Nasionale Party wat waarskynlik net so sterk oor die Christelik-nasionale gedagte gevoel het, maar tog nie die weg van Stoker en ander opgegaan het nie. ${ }^{7}$

Talle individuele universiteitsdosente asook ' $n$ klein groepie dosente en studente en ander universiteitspersoneel het egter later wel in wetenskaplike geskrifte en in populêr-wetenskaplike publikasies 'n duidelike kritiese geluid met betrekking tot sosio-politieke kwessies en onreg laat hoor. Hierdie bestendige stroom van kritiek het in die openbare pers en in die volksmond die benaming 'Die stem van Potchefstroom' verwerf. Die historiese verankering in die Afrikanergemeenskap het egter verhoed dat die universiteit ' $n$ kritiese weg gemaklik sou inslaan, omdat daar geoordeel is dat dit onherroeplik ' $n$ vervreemding van die eie ondersteuningsen kultuurgemeenskap in die hand sou werk.

In die loop van die tyd was dan ook van verskillende kante ernstige kritiek geformuleer op twee fasette van die idee van 'Christelike-nasionaal' naamlik die dualisme inherent daaraan, en die oorwig van die 'nasionale' beginsel in die interpretasie van die inhoud en betekenisreikwydte daarvan (Van der Walt, 1976: 397; Bingle, s.j.). Hierdie verstrengeling van die Christelike belydeniskarakter van die universiteit met die 'nasionale', oorwegend geïnterpreteer as die tradisionele, bykans monolitiese histories-politieke lyn van die Afrikanervolk (Nasionale Party), is deur die historiese gebeure in die internasionale inter-universitêre verhoudinge rondom 1975 en 1976 voor ernstige uitdagings geplaas. In hierdie tyd vind daar naamlik ' $n$ belangrike diskussie tussen die Vrije Universiteit van Amsterdam en die PU vir CHO plaas wat onder andere belangrike konsekwensies gehad het vir die posisie van die PU in die internasionale geledere van inrigtings vir Christelike Hoër Onderwys en tekenend is vir duidelik teenoormekaarstaande opvattinge oor die aard van die Christelike universiteit.

7 Dit is opmerklik dat icmand soos J.H. Coctzce, sclf 'n geïntemeerde tydens die Tweode Wêreldoorlog, 'n baic sterker kriticse geluid as H.G. Stoker ten opsigte van die beleid van apartheid in later jarc laat hoor het. Vgl. sy redaksionele artikels in die tydskrif Woord en Daad. 


\subsection{Vervreemding}

Die feit dat dr. C.F. Beyers Naude, Direkteur van die Christelike Instituut en houer van 'n eredoktorsgraad van die Vrije Universiteit van Amsterdam ingesluit is in die afvaardiging van die Vrije Universiteit van Amsterdam na die Eerste Internasionale Konferensie van Gereformeerde Inrigtings vir Christelike Hoër Onderwys vanaf 9-13 September 1975 in Potchefstroom - 'n konferensie wat deur die PU gereël is, het daartoe aanleiding gegee dat die PU die uitnodiging aan die VU na hierdie konferensie teruggetrek het. Die faktore wat almal hierin ' $n$ rol gespeel het, kan nie hier volledig uitgespel word nie. In die korrespondensie, standpuntstelling en dialoog wat rondom hierdie gebeure gevolg het, het dit algaande duidelik geblyk dat hierdie twee reformatoriese inrigtings besonder sterk verskil het wat betref die interpretasie van wat die Christelike beginsels vir die bestaan van ' $n$ Christelike universiteit en die beoefening van Christelike wetenskap sou beteken. Hierdie verskil blyk duidelik uit die volgende sitaat:

Although the P.U. and F.U. have basic principles in common, it became evident earlier that, in the application of these principles, fundamental differences in viewpoints arise between our universities regarding the task and function of a Christian university. (Free University, 1975.)

Volgens die Vrije Universiteit was een van die kernsake waarom dit in hierdie diskussie gegaan het, die verantwoordelikheid van die Christen-akademikus in die samelewing en die besondere kritiese roeping en taak van die Christelike universiteit ten opsigte van sake soos sosiale geregtigheid en rasse-aangeleenthede. Die PU vir CHO het egter deelname aan en uitsprake oor dergelike kwessies as 'politieke aangeleenthede' beskou en die standpunt gehuldig dat die universiteit as universiteit geen eksplisiete uitsprake oor politieke aangeleenthede moes maak nie, maar dat individuele personeellede wel die reg het om ten opsigte van politieke aangeleenthede standpunt in te neem. Waarskynlik was die PU in dié stadium ontoereikend bewus van die feit dat sy standpuntstelling gesien sou kon word as implisiete politieke betrokkenheid by en sanksie van 'n onregverdige politieke bestel (vgl. Botha, 1978:49, 53). Die PU het op sy beurt die VU kwalik geneem dat hy die weg van sekularisasie opgegaan het en nie meer getrou was aan sy Christelike karakter nie. Hierdie aanklag het veral te make gehad met die wysiging in die grondslagdokumente en die herformulering van die sogenaamde 'identiteitsartikel' van die Vrije Universiteit asook die neiging van die VU om te vir kies vir'n maatskappy-kritiese instelling van die universiteit en die wetenskap. Dit is opmerklik dat in die andersins belangwekkende referaat van H.G. Stoker op hierdie konferensie oor die tema "Our Christian calling of doing science", die aspek van die maatskappy-kritiese taak van die wetenskap en die universiteit nie aangeraak was nie, terwyl dit in daardie stadium juis so 'n aktuele en brandende vraagstuk was (vgl. Stoker, 1976:134-158). 
In die stukke wat na die dialoog tussen die VU en die PU gepubliseer is, blyk dit dat die VU veral moeite gehad het met die vae en ongeartikuleerde inhoud van die sogenaamde 'Christelik-historiese' karakter van die PU (VU, 1976:23). Hulle beswaar was onder andere teen die feit dat die karakter van die PU statutêr besonder vaag geformuleer is, sodat dit nie duidelik was wat die 'Calvinistiese karakter' van die PU presies beteken het nie: Neo-Calvinisties in die spoor van A. Kuyper en/of "naar een eigen Zuid-Afrikaansche Calvinistische traditie".

Tydens hierdie fase van krisis, vervreemding en dialoog tussen die Vrije Universiteit en die PU vir $\mathrm{CHO}$ het die Vrije Universiteit duidelik laat blyk dat hulle besig was met 'n radikale herbesinning oor die staanplek en taak van die Christelike universiteit in die moderne nasionale en internasionale bestel. Die Vrije Universiteit het bewustelik gekies teen die idee van die universiteit as "bolwerk" (bulwark) met die daaraan verbonde implikasies van isolasie in die samelewing en vir die betrokkenheid van onderrig en navorsing by die bevordering van geregtigheid in die moderne wêreld. ${ }^{8}$

Our point of departure is no longer apologetical, many of us being open to listening to those who have different views. Our thinking is directed towards finding a new common identity, while accepting the plurality of a modem university as a positive factor. (Free University, 1975.)

Die standpunt van die PU hierteenoor was egter dat die insluiting van dr. C.F. Beyers Naude in die afvaardiging van die V.U. na die Eerste Internasionale Konferensie vir Gereformeerde Inrigtings vir Christelike Hoër Onderwys,'n politieke demonstrasie was en in sterk teenstelling tot besinning en bevordering van Bybels-verantwoorde Christelike wetenskap gestaan het.

Die Vrije universiteit van Amsterdam het in die periode vanaf die laat sestigerjare tot 1980 inderdaad ' $n$ belangrike herbesinning oor sy pretensie as Christelike universiteit ondergaan. $\mathrm{Na}$ aanleiding van hierdie herbesinning is die reformatoriese basis van die VU verbreed en in ekumeniese sin geïnterpreteer (Wieringa, 1980:32, 37) en is daar geleidelik al hoe verder wegbeweeg van die gedagte dat die wetenskap op enige wyse gebonde of die uitdrukking sou wees van "gereformeerde beginselen". Die konflik tussen die VU en die PU het daartoe aanleiding gegee dat die bande wat tussen die VU en die PU vir $\mathrm{CHO}$ bestaan het, eensydig deur die VU verbreek is (PU vir CHO: Notule van die Raad, 20/11/74, art. 4.12.3). Dit was dan ook die begin van ' $n$ historiese proses waarin

8 Bowendien het die statutewysiging van die VU in 1970 ook reeds 'n keuse gemaak vir 'n meer ekumeniese interpretasie van die Christelike betrokkenheid en binding aan die Evangelic en 'n duidelike presisering van "het dienen van God en zijn wereld" om die "dienst aan de medemens te beteken" (Brinkman, 1992:10,11) 
die PU vir CHO sy staanplek in die geledere van die Vereniging van Internasionale Inrigtings vir Christelike Hoër Onderwys tot 1992 ontsê is. Instrumenteel in hierdie ontwikkelinge was ook die duidelike polarisasie op die PU-kampus asook die internasionale polarisasie wat in 1976-78 rondom die verskyning van die "Koinonia-verklaring" plaasgevind het. Veral tydens die Tweede Internasionale Konferensie vir Inrigtings vir Christelike Hoër Onderwys wat in 1978 in Grand Rapids, Michigan, VSA plaasgevind het, het die wyse waarop die PU teenoor die ondertekenaars en ondersteuners van die Koinonia-verklaring opgetree het, duidelike meningsverskille oor die aard en taak van 'n Christelike universiteit binne 'n aanvegbare politieke bestel in die geledere van die anwesiges aan die lig gebring. Die kruks van die meningsverskil was die vraag in hoeverre ' $n$ universiteit en sy personeel die taak en roeping het om binne ' $n$ politieke bestel waarin onreg voorkom, profeties-krities teenoor die bestel te staan. Dit was die PU veral kwalik geneem dat hy histories in 1869 en later in $1940^{9}$ bereid was om duidelik standpunt in te neem teenoor ' $n$ volksvreemde politieke bestel, maar nie bereid was om sy implisiete verbondenheid aan en betrokkenheid by die heersende apartheidspolitiek aan kritiek bloot te stel nie.

Deur hierdie gebeure het daar geleidelik 'n skeiding van die weë tussen internasionale verteenwoordigers van inrigtings vir Christelike Hoër Onderwys plaasgevind het - veral op grond van uiteenlopende interpretasies van die aard en taak van 'n Christelike universiteit. Net so belangrik is die feit dat hierdie gebeure baie duidelik aan die lig gebring het dat universiteite eenvoudig ingebed is in die kulturele en politieke omstandighede waarbinne hulle bestaan en dat die visie op die roeping en taak van wat as ' $\mathrm{C}$ Christelike universiteit beskou word, ook sterk hierdeur bepaal word. Die VU se sterk beklemtoning van die maatskappykritiese funksie van die universiteit toon in daardie stadium net so sterk die invloed van die heersende maatskaplike en filosofiese beskouings wat in Europa aan die orde van die dag was ${ }^{10}$ as wat die PU se onkritiese instelling ten opsigte van die heersende politiek in die Republiek van Suid-Afrika dit toon. Dit is op sigself nie vreemd nie - inteendeel - illustreer dit een van die belangrikste insigte

9 In hierdie verband word verwys na sommige van die PU-personeel. Prominente figure aan die universiteit soos onder andere proff. H.G. Stoker, D.W. Kruger en F.J. Labuschagne is as gevolg van hulle standpunte en simpatie met die Ossewa Brandwag geïnterneer in die periode rondom 1940

10 In die literatuur word verskeie verklarings aangetref vir die houding en optrede van die Vrije Universiteit en die Nederlanders teenoor die PU. Die mees gangbare is die opvatting dat Nederlanders so krities tecnoor die RSA sou wees omdat dit 'n stamland is wat in dieselfde Calvinistiese tradisie staan as die Nederlandse kultuur. Eppink (1990:98) redeneer egter dat die Nederlanders as skuld- en boetedoening vir die feit dat hulle tydens die Tweede Wêreldoorlog geen versetstryd gevoer het nie, Suid-Afrika en die apartheidsbestel as die teiken van hulle 'versetstryd' opgestel het. 
M. Elaine Botha

van die moderne wetenskapsfilosofie, naamlik dat wetenskap altyd 'n baie duidelike plaaslike stempel en kleur dra (Van Woudenburg \& Birtwhistle, 1988).

In samehang hiermee groei egter ook die insig dat die Kuyperiaanse gedagte dat die Christen-wetenskaplike van bepaalde beginsels vertrek en vandaar die hele gebou van die wetenskap oprig," eenvoudig nie werklikheidsgetrou is nie. (Hierdie Kuyperiaanse gedagte dui op die sogenaamde ekspressiwistiese opvatting van wetenskap - vgl. Wolterstorff, 1988:18; Brinkman, 1992:10.) Selfs aan die Vrije Universiteit van Amsterdam met sy tradisie en formulering van die sogenaamde 'identiteitsartikel' in sy Statuut, waarin die Christelike identiteit van die universiteit per wetgewing vasgelê is, is hierdie 'gereformeerde beginsels' nooit spesifiek geartikuleer nie (Brinkman, 1992:10, 11; hy verwys na die 1970 . voorstelle tot wysiging van die VU-statuut; vgl. ook Wieringa, 1980 \& Venter, 1978). Wetenskap en filosofie (beginsels) is veel eerder 'n sirkulêre proses wat mekaar wedersyds beïnvloed. In hierdie proses speel die wetenskaplike as tyden kultuurgebonde deelnemer ' $n$ besonder belangrike rol.

Opvallend genoeg loop die weë oor die aard en karakter van Christelike universiteit-wees weer sterk uiteen in die laat tagtigerjare wanneer die post-modernisme sy invloed laat blyk (vgl. Brinkman, 1992 en Wolterstorff, 1988). Die postmodernisme word gekenmerk deur nihilisme, relatiwisme en fragmentasie. Omdat die evangelie hierop antwoorde moet formuleer, roep dit ook die Christelike universiteit tot verantwoording oor sy spesifieke taak ten opsigte van die karakter van die moderne kultuur. In die Suid-Afrikaanse situasie word hierdie uitdaging nog verder versterk deur die politieke bewinds- en beleidsverandering.

\section{7. 'n Christelike universiteit in 'n post-apartheidsamelewing?}

Die bekende kontoere van die apartheidsamelewing, waarbinne die Christelike universiteit wat ons vandag ken tot 'n hoë mate ontwikkel en vorm aangeneem het, verdof geleidelik ten einde plek te maak vir die nuwe post-apartheidsamelewing waarin allerweë aanvaar word dat rekonstruksie en ontwikkeling in die 'transformasieproses' van die samelewing sentraal sal staan en dat die universiteit daarin 'n belangrike rol sou moes speel. Die belangrike vraag is egter: Hoe lyk 'rekonstruksie en ontwikkeling' as dit op die agenda van die Christelike universiteit staan? Hoe dwingend hierdie eis ook al na ons toe kom, hetsy vanuit die praktyk van ons ervaring of vanuit die eise van 'n nuwe politieke bestel, bly dit

1 Hicrmec dui Wolterstorff (1988:18) en Brinkman daarop dat die opvatting sou bestaan dat daar ewige, vaste beginscls sou wecs wat in die wetenskap tot "ekspressie" sou kom (Vgl. Brinkman, 1992). Wolterstorff kontrasteer hierdie "ekspressionistiese" visic met een waarin die beoefening van Christelike wetenskap gesien word as ' $n$ "... ongoing conversation and practice in which the Christian participates". 
Christelike universiteit en politiek in 'n apartheids- en post-apartheidsbedeling

die taak van die universiteit om nie sy riglyne vanuit die heersende politiek te aanvaar nie, maar om vanuit eie innerlike missie te omlyn hoe rekonstruksie en ontwikkeling lyk wanneer dit teregkom in die gietvorm van universitêre taakvervulling, dit wil sê wetenskapsbeoefening, onderrig en gemeenskapsdiens.

Sou die bestaansreg van ' $n$ Christelike universiteit in ' $n$ post-apartheidsbedeling anders gefundeer moet wees as in die apartheidsera? Hoewel die Christelike universiteit in die tyd van apartheid sy eie barensweë geken het, was dit kennelik in die era van apartheid gemakliker vanweë die oorwegend 'Christelike' karakter van die samelewing om sy bestaansreg te regverdig as wat dit waarskynlik in die toekoms gaan wees. Waaraan sou dit toegeskryf moet word? Moontlik 'n te gemaklike akkommodasie van die Christelike universiteit aan die politieke eise van die verlede?

'n Begronding of fundering van die bestaansreg van 'n Christelike universiteit is nie in die eerste plek afhanklik van die politieke kleurveranderinge of sosio-politieke transformasieprosesse wat hom in die omringende samelewing voltrek nie. Die reg tot 'n eie bestaan het te make met die aard en missie van die universiteit as samelewingsinstelling met 'n eie en unieke taak in die samelewing. Natuurlik staan die universiteit nie vreemd teenoor die aktuele transformasieprosesse nie, maar moet dit ook by uitstek by dié prosesse betrokke wees en selfs daarin op tipies wetenskaplike wyse leiding gee. Sy bestaansreg egter lê op 'n ander vlak: 'n universiteit ontleen sy reg tot bestaan aan die struktuurnorme wat sy missie reguleer.

'n Subtiele erosieproses het egter reeds die noodsaaklike bindmiddel van 'n potensieel gemeenskaplike (Christelike) waardesisteem van binne uit ondermyn 'n waardesisteem wat die basis van die Christelike universiteit in die nuwe politieke bedeling moet vorm. Hier word verwys na die alles deurdringende effek van die post-modernisme met sy beklemtoning van skeptisisme, pluralisme en relatiwisme. Waarskynlik stel juis die post-modernisme met sy erkenning van die pluraliteit van waardes en keuses 'n heel spesifieke uitdaging aan die Christelike universiteit wat in sy taakvervulling die universele en tyd-transenderende eise van die evangelie konkreet moet vorm gee in die gefragmenteerde en pluralistiese kultuur van ons tyd. Gelukkig maak juis die post-modernisme dit aan die ander kant moontlik om die pluraliteit van alternatiewe perspektiewe in die wetenskap, en kultuur te erken. Tweedens mak die bykans universele erkenning van die paradigmatiese bepaaldheid van die wetenskap en by name die erkenning van die wesenlik epistemiese rol wat sogenaamde nie-epistemiese faktore soos kultuur, tradisie, geskiedenis en religie in die geskiedenis en die beoefening van die wetenskap speel, dit moontlik om juis die agterhaalde tweedeling van religie en wetenskap te verwerp. Maar ten spyte van hierdie gunstige newe-effekte van die post-modernisme gaan die bestaan van die Christelike universiteit ' $n$ proses van 
innerlike transformasie verg. Hiervoor is die deursigtigmaking van die besluitnemingsprosesse en die demokratisering van gesag waarskynlik 'n voorvereiste - en dit nie slegs terwille van die algemene kreet van demokratisering of die potensiële studenteverset teen die status quo nie, maar omdat die gesagsbeskouing van tradisioneel-Christelike universiteite dikwels juis in die teken staan van ' $n$ rigiede, outoritêre en hiërargiese wyse van gesagshandhawing. Veral die beklemtoning van die demokratisering van die universiteit sou seker as gevolg van die inspraak van verskeie groepe in die bestuur van die universiteit ' $n$ koerswysiging in die hand kon werk - 'n koerswysiging wat betref die karakter van die universiteit. Die kritieke kwessie in hierdie verband sal uiteraard die afhanklikheid van finansiering deur die owerheid wees en die mate waarin aan die universiteite in die algemeen van owerheidsweë nuwe voorskrifte met betrekking tot grondslag, karakter en taakvervulling gestel sal word.

Wat die interne funksionering en taakvervulling van die Christelike universiteit betref, impliseer die sentrale taak van die universiteit die volgende: wetenskapsbeoefening wat gestalte kry in onderrig, navorsing en gemeenskapsdiens. 'n Voorwaarde hiervoor is die bestaan van 'n egte universitêre gemeenskapsgees (Botha, 1987:66). Die ontwikkeling en kultivering van 'n Christelike akademiese gemeenskapsgees moet instrumenteel wees in die vorming en ontwikkeling van die intellektuele en persoonlikheidspotensiaal van die student. Die aanwesigheid van en funksionering van hierdie gemeenskapsgees is die onontbeerlike voorwaarde vir die ontwikkeling van profeties-kritiese studente wat in staat is om in hulle eie samelewing getuies te wees van die vernuwende krag van die evangelie op alle lewensterreine. Hierin bestaan die roeping en taak van die Christelike universiteit, naamlik om as gemeenskap-van-geleerdes akademies gedissiplineerde (deur wetenskaplike dissipline en dissiplines gevormde) getuies te wees wat in alle fasette van die menslike lewe geroepe is om "storievertellers" te wees van die "groot dade van God" (Ps. 78: "Sodat die volgende geslag dit kan weet", vgl. ook Seerveld, 1978). Dit is dus essensieel dat die universiteitsgemeenskap sy taak verstaan in die nuimer konteks van die gemeenskap van die gelowiges op weg in 'n wêreld wat aan God behoort. Dit spreek vanself dat 'n Christelike universiteit toegewyde gelowige akademici verg wat bereid is om die eise wat gedissiplineerde Christelike wetenskapsbeoefening stel, na te kom. Meer as ooit tevore verg dit van die PU die morele moed om standpunt in te neem, ook wanneer die unieke karakter en aard van die Christelike universiteit hom waarskynlik binne 'n nuwe politieke bestel ' $n$ anomalie sou kon maak. As die Christelike universiteit in 'n toekomstige bedeling en bestel getrou wil wees aan sy roeping, sal hy sorgvuldig moet soek na die vormgewing van sy taak wat in die teken sal staan van die kenmerke van die Koninkryk: geregtigheid en vrede - dat hierdie vereiste 'n herformulering van sy taak impliseer, is voor die hand liggend. Dat hierdie vereiste sal impliseer dat die Christelike universiteit sy taak veel sterker in die teken van diensbaarheid aan 'n ontwikkelende wêreld sal moet sien, 
Christelike universiteit en politiek in 'n apartheids- en post-apartheidsbedeling

spreek bykans vanself. In hierdie verband sal veral die uitdagings wat die oop deur na die hele Afrika aan die Christelike universiteit stel, verbeeldingryke stappe vra. Hierdie oop deur vereis die deurbreking van die taalisolement van die Afrikaanstalige Christelike universiteit, die verruiming van die visie op die behoeftes en die eise van 'n ontwikkelende Afrika en die verstelling van die samestelling van die universiteit op die vlak van studente, dosente, administrasie en bestuur sodat dit die komplekse en multikurele aard van die Afrika waarvan dit deel vorm, reflekteer.

Een van die kritieke areas waaroor die $\mathrm{PU}$ vir $\mathrm{CHO}$ as Christelike universiteit hom in die komende jare sal moet verantwoord, sal seker die verhouding tot ' $n$ owerheid wees wat waarskynlik veel minder natuurlike begrip vir die Christelikhistoriese karakter van die PU aan die dag sal sê. Juis die bestaansreg van 'n afsonderlike selfstandige inrigting met eksplisiete lewensbeskoulike oriëntasie sal in 'n nuwe politieke bedeling deeglik verantwoord moet word. Vervolgens word kortliks by hierdie aspek stilgestaan.

'n Reformatoriese visie as algemene lewens- en wêreldbeskouing word daardeur gekenmerk dat dit die Skriftuurlike sleutelterme skepping, sondeval en verlossing in 'n universele en allesomvattende betekenis sien. In die reformatoriese tradisie is die begrip religie oorwegend verstaan as 'n verskynsel wat die totale lewensoriëntasie en gerigtheid van die menslike lewe omvat en daarmee saam ' $n$ waardestelsel en perspektief wat die konsekwensies van hierdie lewensinstelling in en op alle lewensterreine vorm gee, ook op die terrein van wetenskaplike onderrig, navorsing en gemeenskapsdiens. Die implikasie van hierdie standpunt is egter dat ook die tipe onderrig en navorsing en wetenskapsbeoefening wat voorgee asof dit vanuit 'n sogenaamde 'neutrale' of 'sekulêre' perspektief gedoen word, 'religieus' gelaai is met ' $n$ eie perspektief, waardesisteem en lewensoriëntasie (vgl. McCarthy, et al., 1981). Word daar vir 'n oomblik teruggekeer na H.G. Stoker dan merk ons dat hy hierdie sleutelgedagte (Stoker, 1967:42-82) op sy tipiese wyse geformuleer as die eis tot die "Christianisering van die hele lewe". Maar dan volg die kenmerkende kwalifikasie: die Calvinistiese lewens- en wêreldbeskouing vertoon volgens Stoker duidelik totalitêr-Christelike kenmerke, maar neem in elke volk 'n besondere, nasionale vorm aan (1967:80). Stoker wil hier veral ruimte laat vir die erkenning van die volle reikwydte van die differensiasie van die mens se gehoorsaamheid aan God in verskillende plekke, tye en geleenthede. Hierdie gedagte word dan ook ruimer en ryker uitgewerk in sy Hoe is ons roeping wêreldwyd? (1963) waarin hy duidelik laat blyk dat rasseverhoudinge deel uitmaak van die ekumeniese taak en roeping van die mens. Hier stel hy:

Ons hele rasseprobleem en rassebeleid is ekumenies van aard. Met die gedifferensieerde ontwikkeling van elke rassegroep kom ons voor die ekumeniese vraag te staan van 'n georganiseerde eenheid van die bevolking 
van ons Republiek sonder prysgawe van die verskeidenheid van rasse en volke en alles wat daarmee samhang. Moet die kind nie reeds op skool leer wat - ekumenies gesien - sy houding tot ander mense, volke en rasse in ons land behoort te wees nie?

Van die sentraliteit van die idee van volk en nasie getuig ook Stoker se visie op die drieërlei roepinge wat hy (1967:20) aan die skool opdra, te wete: die vorming tot verantwoordelike individuele persone, nasionale vorming en ekumeniese vorming. Tog ontstaan die vraag onwillekeurig in hoeverre juis die aard van die post-apartheidsamelewing enersyds, en die eise van die egte ekumeniese roeping andersyds die Christelike universiteit nie juis voor die uitdaging stel om sy eksklusiwistiese verbondenheid aan die eie taal- en kultuurgemeenskap te moet deurbreek nie. Gordon Spykman (1983:17) formuleer die noodsaak om globaal en ruim te dink oor die taak van Christelike hoër onderwys soos volg:

... those involved in Christian higher education within a reformational perspective must learn increasingly to think global in view of these four considerations: (1) the wide horizons of the creation order, (2) the Biblical idea of universal office, (3) our shrinking world situation, and (4) the cosmic dimensions of the coming Kingdom

Word daar uitgegaan van die standpunt dat ' $n$ mens se religieuse verbondenheid met God of ' $n$ afgod ' $n$ saak is wat die totale menslike lewe omspan, sal dit ook konsekwensies hê vir die visie op die universiteit en die beoefening van die wetenskap en die plek van die universiteit in die samelewing. Moontlik kan hierdie konsekwensies die gemaklikste vir die doeleindes van die artikel onder die temas van strukturele en konfessionele pluralisme tuisgebring word - $n$ bruikbare onderskeiding wat deur ' $n$ taakgroep van Calvin College in die VSA nader omlyn is tydens ' $n$ navorsingsprojek oor die bestaansreg van Christelike skole in die VSA (McCarthy, et al., 1981). Die erkenning van strukturele pluralisme impliseer dat daar 'n ryke verskeidenheid van samelewingsverbande bestaan in die samelewing wat elk sy eie soewereiniteit en taak het. Juis die reformatoriese samelewingsvisie met sy beklemtoning van strukturele pluralisme, soewereiniteit in eie kring en die neweskikking van samelewingsverbande is ' $n$ onmisbare voorwaarde vir die bestaan van 'n regstaat en die voortbestaan van die demokrasie. Grondliggend aan konfessionele pluralisme is die erkenning van die lewensbeskoulike diversiteit van die samelewing en die vrye reg van mense met verskillende geloofsoortuiginge tot die uitlewing van hierdie oortuigings in die samelewing, die staat, skole en universiteite met die nodige regsbeskerming.

Ten opsigte van die verhouding van die universiteit tot die kerk en die staat is die reformatoriese standpunt dat om 'n Christelike universiteit te kan wees, die universiteit per definisie ' $n$ vrye universiteit moet wees, dit wil sê vry van die inmenging van sowel die staat as die kerk, in tipiese universitêre aangeleenthede. Word die vrye Christelike universiteit deur die staat gesubsidieer, dan het die staat hoogstens die reg 
Christelike universiteit en politiek in 'n apartheids- en post-apartheidsbedeling

om bepaalde eise met betrekking tot die standaarde en akkreditasie van die werk van so ' $n$ inrigting te stel. Die staat het nie die reg om aan die universiteit voor te skryf wat sy identiteit of karakter sal wees nie (Van der Walt, 1993:3-6) - die Christelike universiteit moet dit self bepaal. Aangesien die gemeenskap van Christelike burgers ook belastingpligtiges is, het hulle die reg om aanspraak te maak op dieselfde finansiële ondersteuning as ander lewensbeskoulike groepe in die staat (Reinecke, 1992:16, 17). 'n Vrye Christelike universiteit is egter geen kerklike universiteit nie, omdat die Christelike universiteit se geloofsuitgangspunte nie deur die kerk voorgeskryf of geformuleer word nie en die Christelike universiteit ook nie onder die bestuur of die voogdyskap van die kerk staan nie.

Hierdie konfessionele karakter van die Christelike universiteit roep die vraag op of religieus gerigte onderwys met die sogenaamde diskriminasieverbod versoenbaar is.

\subsection{Religieus gerigte onderwys, akademiese vryheid en diskriminasie}

Pienaar (1993) stel dat juis die fundamentele reg tot geloofsvryheid inherent in teenspraak is met die diskriminasieverbod wat meestal die sluitsteen van enige menseregtehandves vorm. Juis hierdie oënskynlik onversoenbare stellings verg dus een of ander vorm van versoening. Dit bly egter myns insiens 'n ope vraag of konfessionele en religieus-gerigte onderwys noodwendigerwys diskriminerend van aard is, altans in die sin dat bepaalde voorregte mense ontneem word wat kragtens hulle natuurlike menseregte daarop geregtig sou wees.

Wanneer 'n universiteit geen geloofstoets as voorwaarde of eis tot toelating aan voornemende studente stel nie, sou dit heel moeilik geargumenteer kon word dat daar op enige wyse teen die studente gediskrimineer kon word. Bevind sodanige student haar nou uit eie vrye keuse aan 'n konfessionele inrigting, dan sou sy hoogstens kon eis dat die religieuse perspektief van die dosent op die studiemateriaal haar nie opgedring sou kon word nie, of dat dit van haar vereis word om dit onkrities te moet aanvaar nie.

Dit is waarskynlik anders gesteld met die vraag of die stel van 'n geloofstoets van enige aard aan ' $n$ dosent as diskriminasie gesien sou moes word. In so 'n situasie word eksplisiet gevra na die geloofsoriëntasie van die dosent en word ander wat nie hierdie geloofsoriëntasie deel nie, by voorbaat uitgeskakel en gediskwalifiseer. Kennelik maak die grondwetlike reëlings van die Nuwe Grondwet voorsiening daarvoor dat so 'n situasie nie noodwendig as diskriminasie gereken sou kon word nie. Artikel 32 bepaal:

Elke persoon het die reg

(a) op basiese onderwys en op gelyke toegang tot onderwysinstellings; 
(b) op onderrig in die taal van sy of haar keuse waar dit redelikerwys uitvoerbaar is; en

(c) om, waar dit uitvoerbaar is, onderwysinstellings gebaseer op ' $\mathrm{n}$ gemeenskaplike kultuur, taal of godsdiens tot stand te bring, met dien verstande dat daar geen diskriminasie op grond van ras mag wees nie.

Veral punt (c) maak daarvoor voorsiening dat onderwysinstellings op grond van godsdienstige oortuigings tot stand gebring mag word. So sou 'n Moslemskool of -universiteit dus nie van diskriminasie beskuldig kan word wanneer 'n geloofstoets aan sy onderwysers of dosente aangelê word nie. Hierdie formulering sou waarskynlik die reg van die PU vir CHO op sy eie karakter kon waarborg, hoewel dit in beginsel moontlik sou kon wees dat 'n toekomstige owerheid die begrip godsdiens in die eng sin van die woord kon interpreteer en juis ' $n$ instelling wat dit ruimer verstaan - soos die PU - daardeur op een of ander wyse kan kniehalter. ${ }^{12}$ In die verlengde van hierdie problematiek lê die vraag na die inhoud van die leerstof en die wyse van aanbieding wat karakteristiek sou wees van sogenaamde religieus-gerigte onderrig. Besware teen sogenaamde konfessionele of religieuse onderrig en wetenskap hang ten nouste saam met die bogenoemde gangbare onderskeiding tussen die sogenaamde 'religieuse' en neutrale sfere waarby dan ook dikwels implisiet veronderstel is dat die konfessionele en religieuse oortuigings privaat en persoonlik sou wees en die openbare sfeer per definisie neutraal. Word egter aanvaar dat alle kennis - insluitend wetenskaplike kennis - binne die konteks van 'n denkraamwerk of paradigma tot stand kom en gedra word deur fundamentele (geloofs)-vooronderstellings oor die werklikheid, die mens, die sin van die lewe ensovoorts dan sou geen enkele vorm van wetenskapsbeoefening as 'neutraal' gesien kon word nie - inteendeel! Daarom verg Christelike wetenskapsbeoefening die sorgvuldige ondersoek van sowel God se openbaring in sy skepping asook in sy Skrifwoord, maar dan deur wetenskaplikes, dosente en studente wat hulle staanplek soek en vind in Christus, die Vleesgeworde Woord van God. Maar hierdie vroom taal bring ons nie veel verder nie as ons nie in staat is om werklik "vrugte te kan dra ... wat daarby pas nie ...", om maar 'n Skrifwoord vir die doel so 'n bietjie in te span. Die Christelike universiteit sal sy bestaansreg waarmaak as hy geloofwaardig is, die vrugte dra wat by sy konfessionele status pas. Christelike wetenskapsbeoefening impliseer dat die gelowige akademikus, gewortel in Christus en in gemeenskap met ander gelowiges in die lig van God se openbaring van sy Woord in die Bybel, die onderskeie wetenskaplike velde van ondersoek as die openbaring van God in sy skepping sal ondersoek. Dit verg die ontwikkeling van 'n verantwoorde Christelike lewens- en wêreldbeskouing, die artikulasie daarvan in 'n Christelik-filosofiese raamwerk en die deur- en uitwerk van

12 Ek dink hicr aan die regering van Ontario in Kanada wat aan sogenaamde Christelike kolleges slegs die reg verleen om sogenaamde 'godsdienstige' grade en nie algemeenwetenskaplike grade toe te ken nie. 
die konsekwensies daarvan in die onderskeie vakfilosofieë en vakwetenskappe. Slegs hierdeur is dit moontlik om die subtiele erosie teen te gaan - 'n erosie wat so gemaklik plaasvind wanneer die universiteit onder die druk van interne en eksteme omstandighede gedwing word om op kardinale punte toe te gee aan gesekulariseerde standaarde wat onderrig en navorsing betref. Maar so ' $n$ instelling verg ook moed om die konsekwensies van hierdie lewensbeskouing vorm te gee in die kurrikulum op so ' $n$ wyse dat die prioriteite van die visie bepalend is en nie die voorskrifte van buiteuniversitêre - en beroepsinstansies nie.

Daar sal seker in die komende jare meningsverskille ontwikkel oor die vraag of hierdie taakvervulling juis ' $n$ universiteit met belydende Christendosente verg al dan nie. Daar gaan reeds stemme op dat dit nie noodwendig 'n voorwaarde vir die bestaan van ' $n$ Christelike universiteit hoef te wees nie en dat blote instemming met ' $n$ Christelike grondslag of die verklaring dat die Christelike grondslag nie geopponeer sal word nie, voldoende sou wees om die bestaan van 'n Christelike universiteit te verseker. In hierdie verband is die ontwikkelinge by geesgenootlike inrigtings in die buiteland moontlik ' $\mathrm{n}$ aanduiding van die keuses wat waarskynlik in die toekoms ook van die PU vir $\mathrm{CHO}$ geverg sal word. Moontlik sal die blote instemming met 'n Christelike grondslag soos aan die Vrije Universiteit van Amsterdam in Nederland, een weg wees wat ingeslaan sou kon word. Die pad wat die geesgenootlike susterinstellinge in Noord-Amerika geloop het, getuig egter van 'n ander altematief: die nougesette toepassing van die keuringsbeginsel van die geloof op sowel dosente en studente en die eis aan die hele universiteitsgemeenskap om in te stem met die Christelike grondslag. Te midde van hierdie twee moontlikhede sal die PU vir CHO in die lig van die tydsomstandighede geroepe wees om 'n eie weg in te slaan. Die unieke karakter van die Christelike universiteit lê duidelike grense en beperkinge op aan die uniekheid van hierdie taakvervulling: die deurslaggewende eis bly steeds die primêre roeping tot gehoorsaamheid aan die eise van die wet, die wil en die Woord van God en die innige verbondenheid aan Christus - die Kurios!

\section{Bibliografie}

BINGLE, H.J.J. 1964. Enkele aspekte van vryheid en verantwoordelikheid van die universiteit. Intreerede by ampsaanvaarding as rektor van die PU vir $\mathrm{CHO}, 14$ Februarie 1964. Koers, 31(7\&8):403-425.

BINGLE, HJ.J. s.j. Liberaal-Christelik, Nasionaal-Christelik en Christelik-Nasionaal. Potchefstroom : Instituut vir die Bevordering van Calvinisme. (Studiestuk 1. Potchefstroom.)

BOTHA, Marthina E. 1978. School in Society. (In The Responsibility of Christian Institutions of Higher Education to Justice in the International Economic Order. Proceedings of the Second International Conference of Reformed Institutions for Christian Higher Education. Calvin College, Grand Rapids, Michigan. 13-19 Augustus 1978. p. 43-66.)

BOTHA, Marthina E. 1985. Moet ' $n$ universiteit 'n bepaalde kultuur dra? Woord en daad, $25(276): 19,20$. 
M. Elaine Botha

BOTHA, Marthina E. 1987. Die universiteit: 'n Gemeenskap van dosente en studente. (In IRS. Venster op die universiteit. Potchefstroom: PU vir $\mathrm{CHO}$. p. 65-84.)

BRINKMAN, H.J. 1992. Identiteit van de Vrije Universiteit. Beschouwing van drs. HJ. Brinkman, voorzitter van het College van Bestuur, bij de opening van de cursus 1992 1993 aan de Vrije Universiteit op 7 September 1992. Amsterdam : Vrije Universiteit

COETZEE, J. CHRIS. 1954. Die Christelike Universiteit. Intreerede as Rektor van die Potchefstroomse Universiteit vir Christelike Hoër Onderwys gehou op 19 Februarie 1954. Koers, 21(5):1-34

EPPINK, Derk-Jan. 1990. "Zuid-Afrika: schuld en boete". NRC Handelsblad, 21-05-90.

FREE UNIVERSITY, AMSTERDAM, 1975. Memorandum on the relationship - between the Free University Amsterdam and the Potchefstroom University for Christian Higher Education. An Exchange of Views on Apartheid

HAUSER, Philip M. 1975. Political Actionism in the University. Daedalus, 104:265-272, Winter

McCARTY, R., OPPEWAL, D., PETERSON, W. \& SPYKMAN, G. 1981. Society, State and Schools. A Case for Structural and Confessional Pluralism. Eerdmans : Grand Rapids.

PIENAAR, G.J. 1993. Freedom of association in the United States and South Africa - a comparative analysis. The Comparative and International Law. Journal of Southern Africa, vol. 26, July, p. 147-171.

PU vir CHO. 1984. P.U. en anderskleuriges. Besluit van die Raad op 22 Junie 1984 oor die toelating van anderskleurige studente. Woord en Daad, 24(265):12 -13, Sept.

REINECKE, C.J. 1989. Rektorale inhuldigingsrede: Die PU vir CHO: Verankerd in sy beginsels en gerig op die toekoms. Koers 54(4):415-431.

REINECKE, C.J. 1992a. Christelike karakter en Afrikaans - Só lyk die PU ná wetwysigings Onderhoud met Johannes Froneman. Woord en Daad, 32(341):16 -19, Winter

REINECKE, C.J. 1992b. National Development and Higher Education: the South African Experience. (In Conference Proceedings on Education and Human Resource development in the Pacific Basin, 20-24 April 1992. Tunghai University, Taichung, Taiwan.)

SEERVELD, CALVIN. 1978. A Cloud of Witnesses and a New Generation. Vanguard: Nov.-Dec.

SPYKMAN, GORDON. 1983. Christian Higher Education in Global Perspective: A Call to Ongoing Reformation. Pro Rege, 9(4):13-25, June.

STOKER, H.G. s.j. "Waarom 'n Christelike universiteit?" Stoker-argief, PU vir CHO, Potchefstroom.

STOKER, H.G. 1952. Pro Lege, Grege et Rege! Die Veteraan: 13-18.

STOKER, H.G. 1961. Beginsels en metodes in die wetenskap. Potchefstroom : Pro Rege Pers.

STOKER, H.G. 1967. Oorsprong en rigting, Band 1. Kaapstad : Tafelberg Uitgewers

STOKER, H.G. 1963. Hoe is ons roeping wêreldwyd? Potchefstroom : Pro Rege Pers

STOKER, H.G. 1976. Our Christian Calling of Doing Science. (In Institute for the Advancement of Calvinism. Christian Higher Education. The Contemporary challenge. Proceedings of the First International Conference of Reformed Institutions for Christian Scholarship, Potchefstroom, 9 - 13 September 1975.)

VAN DER WALT, B.J. 1976. Is die Christelik-nasionale beginsel Calvinisties? Fokus, 4(4):397-410.

VAN DER WALT, B.J. 1993. A Christian University. What it Really Is ... And What It Does Not Want To Be. Word and Action 33(343):3-6, Autumn, 1993. 
Christelike universiteit en politiek in 'n apartheids-en post-apartheidsbedeling

VAN DER WALT, TJAART, 1978. Koers hou in die stroomversnelling. Rede uitgespreek tydens inhuldiging as Rektor van die Potchefstroomse Universiteit vir Christelike Hoër Onderwys op 10 Februarie 1978. (Wetenskaplike Bydraes van die PU vir CHO, Reeks H: Inougurele Redes, nr. 41. Potchefstroomse Universiteit.)

VAN WOUDENBERG, RENE \& BIRTWHISTLE, GRAHAM. 1988. De waan van de Verlichting, de waarheid van het post-modernisme. Een interview met Nicholas Wolterstorff. N.a.v de inougurele oratie aan de Vrije Universiteit van Amsterdam: "The project of a christian university in a post-modern culture", 29 April 1988

VENTER, J.J. 1978. De vraag naar de grondslag van de (Christelijke) universiteit. (In Brüggemann-Kruijff, A.Th., Voorsluis, B. \& Zijlstra, O.K. reds. De taak van de universiteit. Assen: Van Gorcum

VRIJE UNIVERSITEIT. 1976. Verslag van een samenspreking tussen delegaties van de Vrije Universiteit en de Potchefstroomse Universiteit vir Christelike Hoër Onderwys Amsterdam.

WALLERSTEIN, I. 1969. University in Turmoil: The Politics of Change. New York : Atheneum.

WIERINGA, W.J. 1980. De Vrije Universiteit als bijzondere instelling - 1880 - 1980. (In Vrije Universiteit. Wetenschap en rekenschap. 1880-1980. Een eeu wetenschapsbeoefening en wetenschapsbeschouwing aan de Vrije Universiteit. Kampen: Kok. p. 1143.)

WOLTERSTORFF, N. 1988. The Project of a Christian University in a Postmodern Culture Inougurele rede, Vrije Universiteit van Amsterdam. 